\title{
Low-Carbon Pilot Tour and Municipal Government Investment: Taiwan's Experience
}

\author{
Liang-Feng Lin \\ Department of Accounting, National Chengchi University \\ Taiwan
}

\section{Introduction}

In the 1980s the carbon-mitigation strategy of Taiwan focused on the recycling of community waste (Chang and Chang, 1993). In the 1990s and 2000s the strategy shifted to reducing the Green House Effect and introducing low-carbon energy technologies such as wind power, solar power, gas, biomass energy, and other reusable energies. Many policies tried to encourage businesses to development reusable energies such as tax deductions or subsidies. Many researches attempted to evaluate the policy effectiveness of the reduction of the various types of pollution, and most of results found that the reduction effects were not as good as the policy claimed or expected (Lee, 1996, Lee, 2003,Wang, 1999). In recent years, the government has tried to embed green construction, green life and green transportation into people's lives.

The first low-carbon region case developed by the central competence government is Penghu Island. The Ministry of Economics in Taiwan announced a project in November 2010 that Penghu Island was to be established as a low-carbon island and would become a worldwide benchmark of a low-carbon island. The project expects to be completed in 2015 . The estimated achievements include (1) reusable energy comprising $56 \%$ of all energies, which will more than Penghu's total non-reusable power, and (2) $\mathrm{CO}_{2}$ emissions will be $50 \%$ less than the 2005s level, which averaged 2.1 tons per person a year (Council of Economic Planning and Development, 2010).

Penghu was chosen as a low-carbon island because many researchers found that Penghu to be an excellent place to develop wind power (Lee, 2003, Taipower, 1996, Lin, 2010, Council of Economic Planning and Development, 2010). The government is going to invest 8 billion NT dollars (€20 million). However, Penghu is just starting the process, and no solid results have yet emerged.

The idea of a low-carbon energy region in Taiwan is quite new and undeveloped. Most of the studies related to low-carbon life or area assessments focus on carbon emission reduction (Lee and Huang, 2004, Chang, 2008), and the effectiveness of different types of pollution control (Chen, 1992, Huang, Lee, and Jhuang, 2007). Many studies also attempt to provide policy suggestions (Lin, 2010, Lee, 1995). Studies related to Penghu as a low-carbon island focus on either technical skills (Lee 2003, Lee and Huang, 2004, Huang 2009, Huang, Lee and Zen, 2006) or related policy solutions (Wang, 2006, Huang). 
On the other hand, New Taipei City ${ }^{18}$ is the first municipal government to promote a lowcarbon pilot tour in its jurisdiction districts. Pinglin District, a declining mountain city under the jurisdiction of New Taipei City, was the first city to promote a low-carbon pilot tour (LCPT) in 2008. The next year Shuangxi District, a long ignored coal-mining city adjacent to Pinglin, also introduced a similar pilot tour. After promoting such tours for several years, both cities started to enjoy the benefits of the LCPT. The benefits include an increasing number of tourists, economic growth, increased job opportunities and a reduction of carbon emissions. Unlike Penghu's low-carbon island project with billions (NT\$) in investments, the New Taipei City Municipal Government invested very little to achieve a great performance. Therefore, the paper tries to analyze how the low-carbon tours work for both cities in relation to the infrastructure and investments of the municipal city to design and promote the tours. The success of LCPT not only has revived declining cities but has also been effective in raising the awareness of local residents and nonlocal tourists of environmental sustainability while inculcating the idea that creating a green city does not require a huge investment on the part of the municipal city government. The rest of the chapter is organized as follows. Sections II and III introduce Pinglin District and Shuangxi District, low-carbon pilot tours and the benefits from the tours. Section IV concludes the paper.

\section{Pinglin District and the low-carbon pilot tour}

\subsection{Area introduction}

Pinglin District, a 173.83 square kilometer town, is the third largest district of New Taipei City. The town used to be a very important midpoint between Taipei and Yilan going back to the Ming Dynasty. Although mountain ridges in this area resulted in twisting and winding roads, Pinglin still served as an important hub to deliver products from the eastern part to the western part of Taiwan. In addition to its important transportation position, Pinglin is also famous for its Wensan Tea and its beautiful views. However, after 2006, the opening of Highway 5 connected Yilan and Taipei to full traffic, a reduction of travel time from Yilan to Taipei of almost 3 hours. The highway suddenly changed the city from a major hub city to a minor tourist attraction. Pinglin is located upstream of Peishi Creek, the residential water source for the Taipei area; therefore, its city constructions have been subject to restrictions since 1987. The declining economy, a decreasing number of tourists, and limited construction opportunities forced many young people go elsewhere to find better jobs.

\subsection{The Low- carbon pilot tour in Pinglin}

On 2006 June 16, just the second day after Highway 5 opened to full traffic, the once busy traffic of Pinglin suddenly became quiet. As the old saying goes, "a crisis is a turning point." Pinglin is a prime example. In 2008 December 19th, New Taipei City and the Pinglin District Municipal Government (PDMG) designed the first new carbon pilot tour in Taiwan and officially established Pinglin's Low-Carbon Tour Service Center (Wu, 2008). The service

${ }^{18}$ New Taipei City was formerly referred to as Taipei County which was renamed as New Taipei City since 2011. In order to simplify the description, the paper uses New Taipei City and does not use Taipei County. The same rule applies to Pinglin and Shuangxi. 
center tries to combine the promotion of a low-carbon lifestyle with a city tour. It helps local stores to support low-carbon operations. The famous tea industry and its distinctive scenery of mountains and creeks give Pinglin tremendous potential to promote the tourism industry. The low-carbon tour allows tourists to enjoy the beautiful natural local scenery and the town's ample cultural assets; at the same time, it also helps them understand the ecological environment of Pinglin. The most important thing is that the tour boosts the local economy without damaging the local environment.

According to estimates of the Environmental Protection Agency of New Taipei City, a trip from the city to Pinglin creates at least 23 kilograms of carbon per person ${ }^{19}$. Based on the above idea, the low-carbon pilot tour in Pinglin was designed as follows:

1). Walk, bike and commute: The PDMG designed the tour for every Wednesday and Saturday. On Highway 9 at 35.5 kilometer a road block has been set up; only buses with 10 or more persons are allowed to enter the district. Upon entering the district, the PDMG provides a free transfer bus to the Pinglin Tea Industrial Museum and to the entrance of the Jingualiao Community, the major scenic site of the tour. The Jingualiao Community extends along the Jingualian Creek is provided with a fish and ferns observation path where visitors are only allowed to walk, bike, or take the 14-seat electric motorcar. Local tour guides and ecological narrators relate the history and humanities of Pinglin.

2). Seasonal and local foods: The PDMG encourages tourists to consume items from green mark stores (low-carbon stores). The stores provide only seasonal and local foods; styrofoam disposable dishware and plastic bags are prohibited.

3) Carbon coupon: The PDMG also came up with the idea of a carbon coupon in 2009. Consumers use the coupon at green mark stores, whereupon the stores donate $10 \%$ of their sales to the "Tree Planting Fund" (TPF). The concept of the carbon coupon comes from the zero carbon emission tour. According to estimates, by taking the public commuting transportation to Pinglin, walking and biking around the district, then purchasing items at green mark stores, a tourist can approximately reduce about 19 kilograms of carbon emissions per person. In order to neutralize the full 23 kilograms of carbon emissions on the tour, the extra 4 kilograms of reductions will come from planting trees. Therefore, the Pinglin low-carbon pilot tour has also been labeled the "zero carbon tour," since the TPF will use donations to plant trees in certain areas in Pinglin to reduce carbon emissions.

4). There are other low-carbon designs for pilot tours. To further reduce carbon emissions, in 2011 the PDMG built the first solar energy environmental public lavatory in Taiwan. The lavatory uses 6 solar photovoltaic cells, with maximum power generation of 1200 KWh. The estimated carbon reduction is 756 kilograms per year (Chen, 2011). Starting from the current year of 2011, the tour decided to provide a "free electric motor bike service" to offer tourists a free test ride on an electric motor bike to tour the city. Besides the free test ride, the PDMG also built an electric motor bike recharging station, which uses solar photovoltaic technology to generate power. The station is free to encourage those who use electric motor bikes to visit Pinglin.

${ }^{19}$ Huang, J. T., 2011, Card News, http:/ / www.cardu.com.tw/news/detail.htm?nt_pk=27\&ns_pk=10724 


\subsection{Investment by the municipal government}

The total Final Accounts for Pinglin District was NT\$ 564.13 million (13.43 million) in 2010 (New Taipei City Final Accounts, 2010), which ranks 20th of the 29 districts in New Taipei City. However, to promote the low-carbon pilot tour, New Taipei City invested very little in related activities. Pinglin has been the water source for Taipei since 1987, and since then the district has seen limited construction projects. All riverside constructions and bike trials use ecological engineering methods, most of which were completed before 2008. The budget for ecological engineering was NT \$15 million (0.36 million) per year ( $\mathrm{Wu}, 2009)$. The largest single investment was the solar energy public lavatory which cost NT\$20 million. Because of the success of the LCPT, Pinglin won the gold medal for environmental demo community in 2010, and received subsidies from the Environmental Protection Administration. The PDMG received about NT\$7 to NT\$9 million in subsidies for promoting the low-carbon pilot tour from the New Taipei City Municipal Government. Table 1 lists the related investments. The table indicates that the total expenditures of the LCPT comprised approximately $4.5 \%$ of total budget expenditures of Pinglin, which in turn only comprised about $1.21 \%$ of New Taipei City's total expenditures for 29 districts.

Unit: NT Thousand

\begin{tabular}{|l|r|r|r|}
\hline Items & Final Accounts & \multicolumn{1}{l|}{ Note } \\
\hline Ecological Engineering Construction & 15,000 & $2.66 \%$ & Per Year \\
\hline Low-Carbon Pilot Tour & 8,000 & $1.42 \%$ & Per Year \\
\hline Solar Energy Public Toilet & 2,000 & $0.35 \%$ & 2011 \\
\hline Other Operating Expenses for LCPT & 100 & $0.02 \%$ & Per Year \\
\hline Pinglin Final Accounts for 2010 & 564,135 & $100.00 \%$ & \\
\hline New Taipei City Final Accounts for 2010* & $76,507,090$ & & \\
\hline
\end{tabular}

*Pinglin District ranks 20th of 29 districts of New Taipei City in total expenditures and its budget comprised only $1.21 \%$ of total expenditures.

Table 1. Pinglin District Pilot Tour Related Expenditures in 2010 


\subsection{Benefits from the LCPT}

The Environmental Protection Administration of New Taipei City found that the LCPT created the following benefits for Pinglin. The tour attracted 25,460 persons in 2008, and approximately 400,000 persons in 2009 and 2010 in total (with an average of 25,091 per month). In 2008 the tour created NT\$7 million in economic benefits and NT\$410 million in 2009 and 2010 in total. In 2008 Pinglin District hired 49 staff members for the activities and $80 \%$ of them are from the local community; in 2009 and 2010 the tour provided 52 job opportunities for local citizens. In 2008 carbon emission reduction was 48,762 kilograms (equivalent to the planting of 10,000 trees a year), but the number increased to 7,536,248 kilograms (equivalent to planting1,545,027 trees a year) in 2009 and 2010. Table 2 summarizes the benefits from the LCPT (New Taipei City Low Carbon Life Net, 2011).

Pinglin District also was awarded by the Environmental Protection Demo Community from Environmental Protection Administration and NT\$2,000 in subsidies. Besides those tangible benefits, the biggest intangible gains are the increased awareness of environmentalism of the residents, according to District Major Chao-Qin Wang. Within three years the residents have changed from resisting the tour to supporting the tour; from environmental skeptics to green-life believers.

\begin{tabular}{|c|c|c|}
\hline Items ${ }^{a}$ & 2008 & 2009 and 2010 in Total \\
\hline Tourists & 25,460 persons & 400,000 (25091 per month) \\
\hline Economic Benefits & NT $\$ 7,000,000$ & NT $\$ 410,000,000$ \\
\hline Job Opportunities & 39 & 52 each year \\
\hline \multirow[t]{2}{*}{ Carbon Emission Reductions } & $48,726 \mathrm{Kg}$ & $7,536,248 \mathrm{Kg}$ \\
\hline & $10,000 \mathrm{TPE}^{\mathrm{b}}$ a year & $1,545,027$ TPE a year \\
\hline
\end{tabular}

a The first year numbers only include those who registered for LCPT, and the other years also include self-guided tourists.

b Tree Planting Equivalent

Table 2. Summary of Benefits from Pinglin LCPT

\section{Shuangxi District and its low-carbon pilot tour}

\subsection{Area introduction}

Shuangxi District means "two creeks"-- Pinglin creek and Mudan creek, both of which pass through the city. The district is located on the outskirts of Taipei City. The natural environment is not affected by over-development of the metropolitan area, and therefore the district still has ample green resources. The district used to be famous for coal mining in the 1970s, but the industry had been in decline for a long time, and the population decreased from 50, 000 in 1970 to 9,000 in 2006. Like Pinglin, Shuangxi has also been affected by the construction of Highway 5. After the highway opened to traffic in 2006, Shuangxi became even less important than before. However, the low development of the district also became a turning point for developing Shuangxi as an eco-city and a green tourism district. Shuangxi completed a loop bike trail and constructed a bicycle rental station to serve as a 
healthy walking path and bike riding along the ancient trial of Ma-Zhu Keng in 2008. Shuangxi began introducing "Low-Carbon Pilot Tours" from Pinglin in 2009.

\subsection{Low-carbon pilot tour design}

Unlike Pinglin, which, as a relatively isolated city could only be reached by Highway 9, Shuangxi is accessed by highways 2C, 102, 106 and a railroad. The tour is designed as follows:

1). Two Creeks, Two Irons and Low-Carbon Tours: The tour slogan is "Two Creeks, Two Irons and Low-Carbon Tours". Two Creeks refers to the name of Shuangxi. Two Irons refers to a railroad trip to Shuangxi and a bike ride here to reduce carbon emissions. Those wanting to go on such a tour need to register on the Internet. Tour capacity is 202 persons. The Shuangxi District Municipal Government (SDMG) integrates the railway and the bike trail and holds a series of events to promote a happy and healthy low-carbon lifestyle. The local tour guides and ecological narrators combine the history and the humanities of Shuangxi District in providing visitors with an enjoyable "Healthy and Low-Carbon Tour."

2). Happy Farm. The SDMG designated some farms as Happy Farms. Within the farm, each 10 square meters is considered one unit; tourists can be adopted by a person or group to plant vegetables using an organic approach. The tourists can pick up local vegetables on a Happy Farm or purchase vegetables and fruits from local produce centers to promote the local economy.

3). Green Mark Restaurants and Stores. Tourists can have their local vegetables prepared form them at green mark restaurants. In these restaurants, tourists need to prepare their own dishware. (styrofoam disposable dishware and plastic bags are prohibited). All food waste from restaurants are recycled as compost. Similar to Pinglin, the green mark stores only sell local products, do not provide plastic bags, and strictly require garbage to be recycled.

4). The Shuangxi Low Carbon Tour Center provides tourists with low-carbon tour program planning, answer inquires on the bike and electric motor rental service station, and consulting services for low-carbon meals.

\subsection{Municipal government investment}

The total final account for Shuangxi District was NT\$405.164 million (€9.647 million) in 2010 (New Taipei City Final Accounts, 2010), which ranked 25th of the 29 districts of New Taipei City. The Shuangxi District started building an eco infrastructure in the years from 2006 to 2008. The loop bike trial and healthy walking path along with the ancient trial of Ma-Zhu Keng were completed during that period. The New Taipei City District Government provided only NT\$ 15 million per year for each district. The "Two Creeks, Two Irons and Law-Carbon Tours" received around NT \$700 million in subsidies from the City Municipal Government per year. Therefore, the tour-related expenditures were minimal. Table 3 indicates the related expenditures. The tour-related expenditures comprised only $5.45 \%$ of total expenditures, which comprised only $0.53 \%$ of New Taipei City's total expenditures for 29 districts. 
Unit NT Thousand

\begin{tabular}{|l|r|r|r|}
\hline Items & Final Accounts & \multicolumn{1}{l|}{ Note } \\
\hline Ecological Engineering Construction & 15,000 & $3.70 \%$ & Per Year \\
\hline Low-Carbon Pilot Tour & 7,000 & $1.73 \%$ & Per Year \\
\hline Other Operating Expenses for LCPT & 80 & $0.02 \%$ & Per Year \\
\hline Shuangxi Final Accounts for 2010* & 405,164 & $100.00 \%$ & \\
\hline 29 Districts Total Final Accounts for 2010 & $76,507,090$ & & \\
\hline
\end{tabular}

*Shuangxi ranks 25 th of 29 districts in total expenditures and only comprised $0.53 \%$ of the total expenditures of Taipei City.

Table 3. Shuangxi District Pilot Tour Related Expenditures in 2010

\subsection{Benefits from the LCPT}

The Environmental Protection Administration of New Taipei City found that the LCPT created the following benefits for Shuangxi. The tour attracted 6,280 tourists in 2009. and 7,509 persons in 2010(Environmental Protection Administration, 2010). According to the Tourism Bureau's estimation, each tourist spent on average NT \$1,019 per day in Taiwan; therefore, the LCPT of Shuangxi promoted NT \$6,949 thousand and NT \$7,652 thousand in economic benefits for the years 2009 and 2010, respectively. The tour created 15 job opportunities in 2009 and 19 in 2010. Carbon emissions were reduced by 44,807 Kg and $54,673 \mathrm{Kg}$ in 2009 and 2010, respectively, which is equivalent to planting 9,188 and 12,095 trees a year, respectively. Table 4 summarizes the benefits derived from the tours.

\begin{tabular}{|l|r|r|}
\hline Items & 2009 & 2010 \\
\hline Tourists $^{c}$ & 6,820 persons & 7,509 persons \\
\hline Economic Benefits (thousand) & NT $\$ 6,949$ & NT $\$ 7,652$ \\
\hline Job Opportunities & 15 & 19 \\
\hline Carbon Emission Reductions & $44,807 \mathrm{Kg}$ & $54,673 \mathrm{Kg}$ \\
\hline & 9,188 TPE a year & 12,095 TPE a year \\
\hline
\end{tabular}

c. The number of tourists includes only those who registered for the LCPT; unregistered tourists are not included. The same is true for other statistics presented in the table.

Table 4. Summary of Benefits from Shuangxi LCPT

\section{Conclusion}

In 2008 Pinglin, a mountain city in decline, became the first city in Taiwan to promote a lowcarbon pilot tour. The following year Shuangxi, a long ignored coal mining city located near Pinglin, also introduced similar activities. After promoting such tours, both cities immediately started to enjoy the benefits of a low-carbon life style. The benefits include a growing tourism, improved economic growth, an increased number of job opportunities and a reduction of 
carbon emissions. Unlike Penghu's low-carbon island project with its billions dollars of investments, the New Taipei City Municipal Government invested very little to achieve a solid performance. Pinglin and Shuangxi, in promoting low-carbon pilot tours, not only have effectively turned around their declining economies but are also contributing to the sustainability of their homeland. The tours not only teach tourists that low-carbon activities can be fun; they also help residents understand how low-carbon activities can be integrated into their lives. Moreover, from the tours, we have learned that environmental sustainability does not require major investments. Both cities made use of minimal investments to achieve maximum benefits for their local economies and environments.

Once Pinglin began promoting low-carbon pilot tours in 2008, many other cities came to offer similar tours. In 2011 the Tourism Bureau planned 20 low-carbon routes in coordination with the Taiwan Tourist Bus Travel Service. The travel service is designed for tourism planning and the design of bus services. From the major attraction of the Taiwan Train Station, a high-speed train shuttles passengers to popular tourist attractions in Taiwan. This is a positive response to a new low-carbon life.

\section{References}

[1] Chang, Y. C., 2008, Low-Carbon Community: New Sustainability Development Indicators, Tai Ta E-News, January, http:/ /www.delta-foundation.org.tw/epaper/080115/epaper_080115.htm\#a1

[2] Chang, Z., and N. Chang, 1993, Evaluation of the Local Enviornmental Protection Administritation Waste Recycleing Performance, Environmnental Protection Administration, 154 Research Paper.

[3] Chen, W. S., 1992, Blue Sky Again, Pullution Control Status, and Prevention Strategy in Taiwan, Journal of Science, June, Vol 270, http:/ / 210.60.226.25/science/content/1992/00060270/0004.htm

[4] Chen, Y., 2011, "The First Public Restroom in Pinglin." http:/ / travel.mtaipei.tw/index_m.php?ptype=news_view_from2\&id=20844.

[5] Council for Economic Planning and Development, 2010, http://www.cepd.gov.tw/m1.aspx?sNo=0014489.

[6] Environmental Protetion Administritation, 2010, Two Creeks, Two Irons and LowCarbon Tours." New Taipei City.

[7] Huang, C H., 2009, "Measurement of Energy Efficiency in Taiwan and Its Relevance to CO2 Decoupling." Invited paper presented at the Workshop on Innovations in Energy Efficiency. Stanford University, California, February 17-18.

[8] Huang, C. H. , C. Yang, H. Lin, and H. Su ,2006, “The Impact of the Oil Price Shock on CO2 Emissions and the Adoption of Renewable Energy." Paper presented at the International Conference on Regional Carbon Budgets, August 16-18, Beijing.

[9] Huang, C. H., 2007, "Double Dividend Hypothesis: Results from the Energy Tax Initiative in Taiwan." Invited speech presented at the National Institute for Environmental Studies, March 1, Tsukuba City, Japan.

[10] Huang, C. H., C. M. Lee, and F. C. Jhuang, 2007, Pollution Prevention Investment and Innovation Behavior under Carbon Emission Trading Scheme, Taiwan Economic Review, Vol. 35:1, 87-114. 
[11] Huang, J., 2101/10/05, Card News, http://www.cardu.com.tw/news/detail.htm?nt_pk=27\&ns_pk=10724

[12] Lee, C. J., and Huang, Y. C., 2004, Renwerable Energy Policy and Green House Effect of Industrial Developmen, Taiwan Watch Vol.6, No.2 Summer, 52-60

[13] Lee, C. M., C. H. Huang, and U. Zen , 2006. “Optimal Integration of Carbon Tax and Subsidy for Renewable Energy Development." Paper presented at the 2nd International Conference on Environmental History, November 8-10, 2006, Academia Sinica, Nankang, Taiwan.

[14] Lee, C., 2009, Energy Saving and Carbon Risk Reduction Assessment in Energy Intensive Industries in Taiwan, IDMC, 3DSA, Asia Display, Taipei International Center, Taiwan, April 27-30, 2009.

[15] Lee, C., and H. Liu , 2009, Assessment of GHGs Decoupling and Electricity Cost by Low-Carbon Energy Technology Development in Taiwan, The 15th International Joint Seminar on the Regional Deposition Processes in the Atmosphere (RDPA) and Climate Change in 2009, Taiwan/ Taipei.

[16] Lee, S., 2003, The Perspective of Renewable Energy In Penghu, Build a New Ocean Home Penghu Seminar,37 55.

[17] Lee, T., C. M. Lee, and C. Tseng, 2005, “International Emissions Trading Approach to Meet the Kyoto Protocol: The Implications of Trading Hot Air," selected paper presented at 28th Annual IAEE International Conference, June 3-6, 2005, The Grand Hotel, Taipei, Taiwan.

[18] Lee, T., C. M. Lee, and C. Tseng, 2009, International Emissions Trading Approach to Meet the Kyoto Protocol: The Implications of Hot Air, Energy Studies Review,Volume 15 , Issue 2.

[19] Lee, Y. C., 1995, Environment Attitude and Environment Behavior: Theory and Empirical Test, Hu Ltd. Taipei.

[20] Lin, C. W., 2010, Green Energy Development: Establishing a Clean and Low-Carbon Island, Council of Economic Planning and Development News, http:/ / www.cepd.gov.tw/m1.aspx?sNo=0014489

[21] New Taipie City 2010 Budget, 2011, http://www.finance.ntpc.gov.tw/web66/_file/1051/upload/selfpage/30255/1-5.xls.

[22] New Taipie City Low-Carbon Life Net, 2011, http://www.epd.ntpc.gov.tw/web66/_file/1150/upload/news/lowco2/result05.html.

[23] TaiPower, 1996, Evaluation of the Penghu Wind Power Generation Plan.

[24] Wang, T., 1999, Industrial Development, Energy Utilization and National Land Planning, Cross Century National Land Planning Seminar, National Pespective Foundation, Taipei.

[25] Wu, C., 2009, The Experience of Promoting Taipei County's Ecological Engineering, http:/ / eem.pcc.gov.tw/eemadm/files/product_1/ws_29/01.doc 


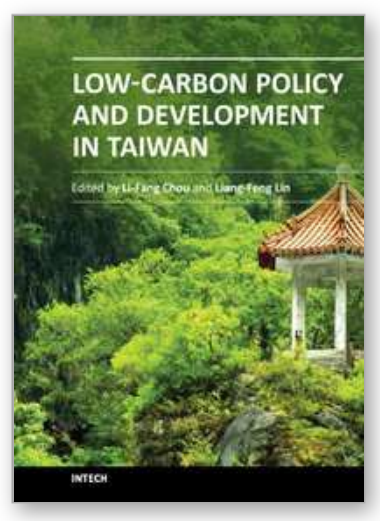

\section{Low Carbon Policy and Development in Taiwan}

Edited by Dr. Liang-Feng Lin

ISBN 978-953-51-0156-7

Hard cover, 97 pages

Publisher InTech

Published online 24, February, 2012

Published in print edition February, 2012

Taiwan a typical small Asian country with few energy resources is well known for its high-tech industry in the last 20 years. However as a member of the global village Taiwan feels the responsibility to reduce carbon emissions. The book tells you how Taiwan transforms itself from a high-tech island to become a low carbon island. The book address Taiwan's low-carbon developmental policies of the past 10 years, applies an econometric approach to estimate Taiwan's sector department $\mathrm{CO} 2$ emissions, shows how environmental change affects the economic growth of Taiwan, and provides two successful examples of low-carbon pilot regions in Taiwan. Stephen Shen, the Minister of the Environment Protection Agency of Taiwan, believes that the book arrives at the right time, because this is the time to educate the people of Taiwan, about the necessary action for achieving a low carbon society.

\section{How to reference}

In order to correctly reference this scholarly work, feel free to copy and paste the following:

Liang-Feng Lin (2012). Low-Carbon Pilot Tour and Municipal Government Investment: Taiwan's Experience, Low Carbon Policy and Development in Taiwan, Dr. Liang-Feng Lin (Ed.), ISBN: 978-953-51-0156-7, InTech, Available from: http://www.intechopen.com/books/low-carbon-policy-and-development-in-taiwan/low-carbonpilot-tour-and-municipal-government-investment-taiwan-s-experience

\section{INTECH}

open science | open minds

\author{
InTech Europe \\ University Campus STeP Ri \\ Slavka Krautzeka 83/A \\ 51000 Rijeka, Croatia \\ Phone: +385 (51) 770447 \\ Fax: +385 (51) 686166 \\ www.intechopen.com
}

\author{
InTech China \\ Unit 405, Office Block, Hotel Equatorial Shanghai \\ No.65, Yan An Road (West), Shanghai, 200040, China \\ 中国上海市延安西路65号上海国际贵都大饭店办公楼 405 单元 \\ Phone: +86-21-62489820 \\ Fax: +86-21-62489821
}


(C) 2012 The Author(s). Licensee IntechOpen. This is an open access article distributed under the terms of the Creative Commons Attribution 3.0 License, which permits unrestricted use, distribution, and reproduction in any medium, provided the original work is properly cited. 